DOI: https://doi.org/10.31933/dijdbm.v2i4 Received: 25 June 2021, Revised: 10 July 2021, Publish: 28 July 2021

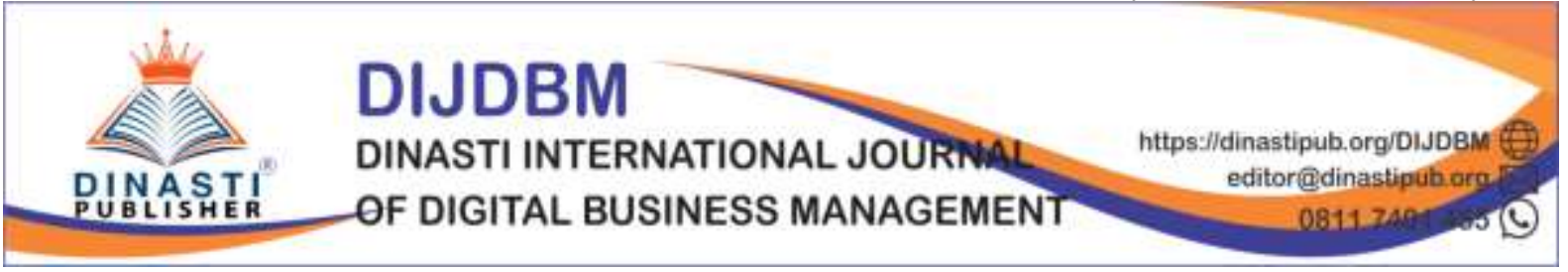

\title{
EFFORTS TO IMPROVE DISCIPLINE OF SERVICE SERVICES ON THE BRIDGE FOR LIFE SAFETY ON THE MV.HTC CHARLIE SHIP
}

\author{
Panderaja Sijabat $^{1}$, Abdul Rochman ${ }^{2}$, Steven Dion Octovianus ${ }^{3}$ \\ 1) Merchant Marine Higher Education, pande.sijabat@gmail.com \\ ${ }^{2)}$ Merchant Marine Higher Education \\ 3) Merchant Marine Higher Education
}

Corresponding Author: Panderaja Sijabat

\begin{abstract}
Mualim has an important role in carrying out ship movement while sailing for the safety of all crew members. In this case the officer has the responsibility to carry out guard duty on the bridge. This study aims to further increase knowledge about the importance of discipline in carrying out guard services on the bridge and to carry out guarding procedures in accordance with established procedures, especially when changing guard (handing over). This research was carried out on board the MV. HTC CHARLIE which is one of the ships owned by PT. INTERGIS. Implementation during the author's practice of the Sea (Prala), so that the source of the data obtained directly from the place of doing research in the form of information based on observations and interviews with the officer in charge. This study shows that there are still shortcomings in carrying out the duty of duty in accordance with the procedures and the lack of discipline of the missionary when on guard duty. By conducting this research, it is possible to make an overview of the watch service in accordance with the procedures for handing over the guard and the importance of discipline in carrying out the watch service on the bridge.
\end{abstract}

Keywords: Service guard, discipline, change of guard, officer, procedure

\section{INTRODUCTION}

Sea transportation is a means of moving people or goods operating at sea. Ships compared to other transportation were chosen to be the main means because in terms of shipping goods can be done in large quantities and the costs incurred are smaller. Basically, ships tend to prioritize more effective and efficient cargo handling.

One of the supports for ship safety is the smooth operation of the ship and the important role of ship personnel when on duty on guard on the bridge. The implementation of the marine guard service requires high accuracy and responsibility in making decisions while the ship is sailing. Small and large accidents that occur on board the ship are mostly caused by the actions or actions of the ship's personnel themselves that are not in accordance with the standard procedures for guard duty. A tanker is one of the means of sea transportation which is a means of transporting liquid cargo or transporting cargo of agricultural products in the form of 
crude oil or those that have been processed into product oil. Tankers have different ship constructions, depending on the cargo to be transported.

The officer who is fully responsible for his duties will process the motion of the ship while sailing to avoid things that are not desirable, especially the danger of ship collisions. Discipline in the implementation of the guard service is very important and must be carried out according to the procedures established by the company and regulations

international. If a discrepancy occurs, it will have a negative impact, namely harming the company, threatening the safety of the ship's crew, and damage to cargo.

MV ship. HTC CHARLIE is an international shipping vessel in the world of shipping known as Ocean-going owned by PT INTERGIS. The ship is loaded with bulk, for example, such as coal, cement, wheat and others that carry out cargo shipments from one port to another. Based on the author's experience when carrying out marine practices on the MV HTC CHARLIE ship, the ship is not yet optimal in the standard procedures for guard duty. First, it can be seen from the officer's lack of discipline while on duty on guard on the bridge, not taking the time to rest (drowsy) so that mistakes often occur in paying attention to the ship's bow This resulted in the ship almost having an accident with another ship. Second, the information provided during the handover of the guard, not clear, resulting in the replacement officer not knowing the ship's situation. Third, the lack of fit of the officers' bodies which made them unfocused during the watch service and lastly, the lack of an active role for officers on the bridge who did not re-observe the condition of the ship.

The author realizes that the discipline of officers in the watch service on the bridge has an important role in the safety of life on the ship. Therefore, the author wants to examine how to improve discipline in the guard service and the factors that cause the handover of guard to not be carried out according to the procedure.

\section{METHOD}

Research is a series of scientific activities in order to solve a problem. Research results are never intended as a direct solution to the problems faced, because research is part of a larger problem solving effort. According to Azwar (1997:1), the function of research is to find explanations and answers to problems and provide alternatives for possibilities that can be used for problem solving.

According to Sugiyono (2007:2), the research method is a scientific method used to obtain data with a specific purpose. The scientific method means that the activity is based on the scientific method, namely rational, empirical, and systematic. Rational means that research activities are carried out in ways that make sense so that they are affordable by human reasoning. Empirical means that the methods used can be observed by the human senses, so that other people can observe and know the methods used. Systematic means that the process used in the research uses certain logical steps. So it can be concluded that research is a scientific method used to find an explanation of a problem.

\section{Approach Method}

In collecting this thesis the author will carry out how the author conducts research and how the author obtains data. In this case the author uses the approach method and data collection techniques in the form of: 
a. Case study

The research case study approach method is carried out to develop understanding by describing in depth a case that is the focus of research. The author discusses the issue of discipline in guard personnel and guard handover procedures.

b. Problem Solving

A problem approach where the author finds and solves problems based on accurate data and information on board the MV.HTC.CHARLIE and other reference sources, so that appropriate and accurate conclusions can be drawn regarding the problems that occur on the ship.

c. Qualitative Descriptive

Qualitative descriptive method is to produce descriptive data in the form of words or verbal from the results obtained in observation and using analysis. The research was conducted on the aspect of in-depth understanding of a problem studied on a case by case basis and data were collected in full.

\section{Data collection technique}

Complete, objective and accountable information data for processing and presented as an overview and view that can assist in the preparation of this thesis. In this case, data and information were collected using the following techniques:

1. Observation

The collection and information using observation techniques means directly observing and examining the object. Observations were made while undergoing a marine project aboard the MV. HTC CHARLIE and while on duty on the bridge. In this observation technique, the objects observed by the author are:

a. Execution of guard duty on the bridge

b. Discipline of guard personnel when carrying out guard duties on the bridge

c. Readiness of information provided at the time of handover guard at the bridg

2. Interview

Interview is a data collection technique that is also used by the author by communicating or asking directly to the parties related to the implementation of the guard service on the bridge aboard the MV. HTC CHARLIE. This interview method is quite effective in getting a more detailed explanation of the chronology of several events or many things that are not understood in connection with the topic to be discussed. The author interviewed the officer in charge, so that data can be obtained that can be used as material for the author's observations

\section{Data analysis technique}

The author uses descriptive - qualitative in analyzing, where the author tries to describe the problems that occur, namely starting from the factors that cause the lack of discipline of the guard officers when carrying out guard duties on the bridge, such as not implementing the guard handover procedure in accordance with the standard, preparation - the preparations made before carrying out the handover while on duty on the bridge are still lacking, the physical readiness of the guard personnel when carrying out guard duties on the bridge and describes all the experiences that have been obtained in accordance with concrete data during the author's sea project.

Besides that, the author also tries to provide problem solving for each inhibiting factor and provides good suggestions based on existing theories and knowledge obtained by the author from officers on board. 


\section{RESULTS AND DISCUSSION}

\section{The officer's lack of concentration while on guard duty on the bridge.}

The officer's lack of discipline regarding his responsibilities while carrying out his watch duties also affected the concentration of the officer, as seen at the time of changing the watch from Commander II to Commander I, at that time the position of the ship being sailing would enter the channel to the loading port at Vissai and there was a tugboat delaying the barge. which is loaded with coal which will cut from the starboard side of the MV. HTC CHARLIE. When the Commander II handed over his guard to the Commander I, he had already informed that there was a tugboat at the bow of the starboard side that would cut the bow which was still 5.5 Nautical Miles away. After receiving information about the situation around the ship, the Mualim I only answered "yes" and immediately sat on a chair without taking into account the surroundings.

When the tugboat crosses the position of the MV. HTC CHARLIE has seen the red hull light, then the cadet checks on the radar it turns out the tug has been 3.0 Nautical Miles. so that at that time the cadet immediately reported it to the Commander I. But the Commander I who had just climbed onto the bridge and was still in a sleepy condition gave orders to the helmsman to change course to the left. After the helmsman changed course and observed carefully, if the ship continued to change bow to the left, the ship will collide with the tug. Finally, the helmsman told the first officer that the ship would have a collision if it continued to change course to the left, because the ship would meet between bows and tugboats.

From the results of the observation of the problem according to the attachment of the interview with the Mualim I, the author concludes that the causes of the lack of discipline in his responsibilities while carrying out guard duties are:

a. Mualim I did not use his rest time well before his watch. Because he didn't use his rest time properly, Mualim I felt tired and didn't concentrate when he was doing his duty on the bridge.

b. Does not take into account the danger of collision when there is a tug that will cut in front of the bow of the ship. In this situation, the guard officer should make periodic observations until the situation is completely free from the danger of collision as attached in P2TL rule 5, namely regarding observation.

\section{The officer did not carry out the handover of the guard according to the procedure.}

In the description of the data that the author has conveyed in the second case, namely when the guard handover process between the first officer on guard duty at $16.00-20.00$ and the third officer on guard duty at $20.00-00.00$, it was found that there were inadequacies in the handover of guard, namely the lack of information. obtained by the substitute guard officer (Mualim Tiga).

From the results of the observations that the author made, it was found the cause of the lack of information obtained by Mualim Tiga at the time of the handover of guard. The causes are as follows:

a. The officer who was replaced (Commander I) was not clear in conveying information when handing over the guard to the third officer, namely only telling the direction of the ship and the surrounding conditions were safe.

b. The supervising officer (Mualim Tiga) did not carry out the guard handover procedure as determined, namely not checking the operational conditions of all navigational equipment and security equipment that were being used or that might be used during 
guard duty, so that the officer in charge was confused how many hours the radar had been running. used.

Procedures before carrying out watchkeeping duties must also be observed, and these standards have been described in the STCW Code on "Watchkeeping Deck". According to the rules, all people who have been appointed to carry out guard duties on the bridge first study the flow and the surrounding weather conditions, check and learn if there is a Master Standing Order and other instructions then sign, record navigational warnings and weather forecast. Arrive at the bridge at least 15 minutes before the change of duty.

The procedure when carrying out the handover of guard duty has also been explained in the Bridge Standing Order. According to the rules when carrying out the handover of the watch, the officer in charge must clearly inform the substitute officer about the records in the Master's order book and other verbal orders, the position of the direction and speed of the ship, target objects and visible lights, the movement of the ship. - other ships in the vicinity, working conditions of all security tools and equipment as well as navigation lights and messages from engineers. This happened in the first incident when the handover of guard between the first officer and the third officer was not in accordance with what had been stipulated in the fixed command of the bridge. Even though the order for this bridge has been pasted and is clearly visible on the bridge.

\section{CONCLUSION}

Based on the results of the analysis of the problems raised in this thesis, it can be concluded that:

1. The lack of discipline of the watch officer during the watch duty on the bridge is the negligence of the officer who does not use the rest time well before the watch hour so that he is sleepy, does not focus on regular observations, and does not take into account the danger of collision when a tugboat will cut in front of the bow of the ship So with the supervision of the captain while on guard duty and punishing undisciplined officers, officers will be more responsible for their duties for the safety of the entire crew.

2. The officer did not carry out the handover of the watch in accordance with the procedure because the officer being replaced did not provide clear information to the officer who would serve on guard and did not fill in the handover of the guard so that in its implementation it was not in accordance with the procedure for handing over the guard.

\section{BIBLIOGRAPHY}

Bridge Watch keeping Second Edition (London : Nautical Press, 2009)

Handoko, T. Hani, Personnel Management and Human Resources (Yogyakarta BPFE, 1987)

Maritime Law 1 ( 2015)

IMO. 2010. Standards of Training, Certification, and Watchkeeping for Seafarers Code Amendments Manila Chapter VIII. London.

Big Indonesian Dictionary (Jakarta : Ministry of Education \& Culture, 2009)

Manikome, Capt EW, Watch Keeping

Risuandi, Capt. Yan (2013), Dina Guard for Mualim and International Regulations on Prevention of Collisions at Sea 1972 Amendments 1981, 1987, 1993, \& 2001. Jakarta

Law of the Republic of Indonesia No. 17 of 2008 concerning Shipping

(http://maritimeworld.com) STCW 2010 Amendment Manila (London : IMO, 2011)

http://www.pelaut.xyz/2017/09/dinas-jaga.html 
https://text-id.123dok.com/document/dy4kk3k5q-pengertian-usaha-pengertianpeningkatan.html 